\title{
THE EFFECTS OF DRUG ABUSE ON THE NATURAL HISTORY AND PROGRESSION OF CHRONIC ACTIVE AND CHRONIC PERSISTENT HEPATITIS
}

\author{
Y. Arthurs, G. D. Doyle, J. F. Fielding* \\ Department of Medicine and Gastroenterology, The Charitable Infirmary, \\ Jervis Street, Dublin 1.
}

\section{Summary}

CHRONIC active hepatitis in drug abusers tends to be a histologically less severe disease than in non drug abusers in whom it may be of the lupoid variety. Chronic persistent hepatitis tends to persist in drug abusers (this may be due to continued abuse) and regress more frequently in non drug abusers.

\section{Introduction}

This paper reports the effects of drug abuse on the natural history and progression of chronic active and chronic persistent hepatitis. This does not appear to have been previously described.

\section{Patients and Methods}

Forty-six of 139 first visit patients who attended the Drug Advisory and Treatment Centre in the Charitable infirmary with a problem of intravenous drug abuse, between May 1st 1979 and December 31st 1979, had liver biopsies carried out. Eight of these patients had chronic active hepatitis; these and 4 other abusers with chronic active, hepatitis who were attending the Department of Gastroenterology, were included in this study. They were compared with the 10 non drug abusing patients with chronic active hepatitis who were attending the Department of Gastroenterology. All patients with chronic active hepatitis were on conventional therapy.

Twenty of the 46 patients had chronic persistent hepatitis; 12 of these had more than one liver biopsy and are included in this study and compared with the 7 non drug abusing patients who were attending the Department of Gastroenterology.

Each patient was personally interviewed by one of the authors (Y.A.). In the case of drug abusers a detailed history of drug abuse was obtained; the duration of abuse, routes of administration and sharing of syringes with others. The alcohol consumption of patients was calculated according to levels of alcohol concentration of various drinks (McCance and Widdowson, 1967). For the purpose of this study alcohol intake was considered mild if less than $80 \mathrm{~g}$ pure alcohol/day, moderate if between $80 \mathrm{~g}$ and $120 \mathrm{~g}$ pure alcohol/day, heavy if greater than $120 \mathrm{~g}$ alcohol/day.

Stigmata of chronic liver disease (finger clubbing, spider naevi, palmar erythema, Dupuytren's contractures, leuconychia, hepatomegaly, splenomegaly, ascites, testicular atrophy and gynaecomastia) and the presence or absence of tattoos were sought in all patients on physical examination. In the case of drug abusers stigmata of such abuse (needle marks, infected skin lesions) were also sought.

\footnotetext{
${ }^{*}$ Requests for reprints to Dr. J. F. Fielding.
}

This article is a reproduction of that published in: Irish Journal of Medical Science, 150(4), April 1981, pp. 104112. Pagination may not match that of the original. 
The following laboratory tests were performed:- haemoglobin, white cell count, erythrocyte sedimentation rate, platelet count, prothrombin time, serum alanine and aspartate aminotransferase, gamma glutaryl transferase, lactate dehydrogenase, alkaline phosphatase, serum bilirubin, $\mathrm{HB}_{\mathrm{s}} \mathrm{Ag}$, anti nuclear factor, smooth muscle antibody and anti mitochondrial antibody.

Liver biopsy was carried out following informed consent. Two or more liver biopsies were carried out in 10 of the 12 drug abusers with chronic active hepatitis, in all the non drug abusing patients with chronic active hepatitis and in all the patients with chronic persistent hepatitis. The histological diagnosis was made in accordance with the criteria

TABLE I

Age, sex and duration of follow up in each group.

\begin{tabular}{lccccc}
\hline Patient group & $\begin{array}{c}\text { Number of } \\
\text { patients }\end{array}$ & Male & Female & $\begin{array}{c}\text { Mean age } \\
\text { (years) }\end{array}$ & $\begin{array}{c}\text { Mean duration } \\
\text { of follow up } \\
\text { (mnnths) }\end{array}$ \\
\hline CAH-drug abusers & 12 & 11 & 1 & 25.6 & 17.9 \\
CAH-non abusers & 10 & 5 & 5 & 34.5 & 39.8 \\
CPH-drug abusers & 12 & 9 & 3 & 24.0 & 15.3 \\
CPH-non abusers & 7 & 3 & 4 & 29.5 & 29 \\
\hline
\end{tabular}

suggested in a review by an International Group (1977). Where patients had more than one liver biopsy the time in months from the initial biopsy is stated.

\section{Results}

The age, sex, duration of follow-up, alcoholic intake, clinical features, biochemical and

TABLE II

Alcoholic intake in each group.

\begin{tabular}{lccccc}
\hline Patient group & $\begin{array}{c}\text { Number of } \\
\text { patients }\end{array}$ & Heavy & Moderate & Mild & Nil \\
\hline CAH-drug abusers & 12 & 3 & 3 & 4 & 2 \\
CAH-non abusers & 10 & - & 2 & 2 & 6 \\
CPH-drug abusers & 12 & 4 & 3 & 2 & 3 \\
CPH-non abusers & 7 & 1 & - & 2 & 4 \\
\hline
\end{tabular}

immunological results are tabulated in Tables I-VII. $\mathrm{HB}_{\mathrm{s}} \mathrm{Ag}$ status on each group is tabulated in Table VIII.

In the drug abusing patients with chronic active hepatitis there was no significant history of associated illness. Of the 10 non drug abusing patients with chronic active hepatitis, one patient was hypothyroid, another had tryrotoxicosis, one patient had ulcerative colitis for which he had a panprotocolectomy 5 years previously, one patient had a duodenal ulcer, and 2 patients had tuberculosis, one of whom was treated with rifampicin and isoniazid for 2 years, one patient had several operations for the reimplantation of an ureter, 3 patients had had blood transfusions. There was no associated illness in the group of drug abusing patients with chronic persistent hepatitis. One of the non drug abusing patients with chronic persistent hepatitis had psoriasis. 
TABLE III

$\mathrm{CAH}$ and $\mathrm{CPH}$. Stigmata of liver disease in drug abusers and non abusers.

\begin{tabular}{lcccccc}
\hline $\begin{array}{l}\text { Patient } \\
\text { group }\end{array}$ & $\begin{array}{c}\text { Number } \\
\text { of } \\
\text { patients }\end{array}$ & $\begin{array}{c}\text { Number of } \\
\text { patients } \\
\text { with } \\
\text { stigmata }\end{array}$ & $\begin{array}{c}\text { Finger } \\
\text { clubbing }\end{array}$ & $\begin{array}{c}\text { Dupuytren's } \\
\text { contractures }\end{array}$ & $\begin{array}{c}\text { Palmar } \\
\text { erythema }\end{array}$ & $\begin{array}{c}\text { Spider } \\
\text { Haevi }\end{array}$ \\
\hline CAH-drug abusers & 12 & 3 & - & - & - & 3 \\
CAH-non abusers & 10 & 6 & 2 & - & 3 & 3 \\
CPH-drug abusers & 12 & 2 & - & - & - & 1 \\
CPH-non abusers & 7 & 0 & - & - & - & 1 \\
\hline
\end{tabular}

TABLE IV

$\mathrm{CAH}$ and $\mathrm{CPH}$. Stigmata of drug abuse in drug abusers.

\begin{tabular}{lccc}
\hline Patient & No. of & Needle & Skin \\
Group & Patients & Marks & Abscess \\
\hline CAH & 12 & 9 & - \\
CPH & 12 & 12 & 3 \\
\hline
\end{tabular}

Two of the drug abusing patients with chronic active hepatitis developed jaundice during the course of follow up. None of the non drug abusing patients with

TABLE V

SGPT levels in CAH.

\begin{tabular}{rcccc}
\hline \multirow{2}{*}{ SGPT U/I } & \multicolumn{2}{c}{ Onset } & \multicolumn{2}{c}{12 months } \\
\cline { 2 - 5 } & $\begin{array}{c}\text { Drug } \\
\text { abusers }\end{array}$ & $\begin{array}{c}\text { Non } \\
\text { abusers }\end{array}$ & $\begin{array}{c}\text { Drug } \\
\text { abusers }\end{array}$ & $\begin{array}{c}\text { Non } \\
\text { abusers }\end{array}$ \\
\hline 45 & 2 & - & 7 & 3 \\
100 & 1 & 1 & 2 & 6 \\
300 & 2 & 3 & 2 & 1 \\
1000 & 5 & 4 & 1 & - \\
2000 & 2 & 2 & - & - \\
\hline
\end{tabular}

chronic active hepatitis did so. In the group of patients with chronic persistent hepatitis all of the drug abusing patients remained clinically well during the course of follow up, 2 of the non drug abusing patients developed jaundice.

Three of the drug abusing patients with chronic active hepatitis claimed to have ceased abusing drugs, one of the drug abusing patients with chronic persistent hepatitis claimed to have ceased abusing.

TABLE VI

SGPT levels in $\mathrm{CPH}$.

\begin{tabular}{rcccc}
\hline \multirow{2}{*}{ SGPT U/I } & \multicolumn{2}{c}{ Onset } & \multicolumn{2}{c}{12 months } \\
\cline { 2 - 5 } & $\begin{array}{c}\text { Drug } \\
\text { abusers }\end{array}$ & $\begin{array}{c}\text { Non } \\
\text { abusers }\end{array}$ & $\begin{array}{c}\text { Drug } \\
\text { abusers }\end{array}$ & $\begin{array}{c}\text { Non } \\
\text { abusers }\end{array}$ \\
\hline 45 & 2 & 1 & 2 & 6 \\
100 & 2 & 1 & 6 & 1 \\
300 & 1 & 2 & 4 & - \\
500 & 3 & - & - & - \\
1000 & 3 & 1 & - & - \\
2000 & 1 & 2 & - & - \\
\hline
\end{tabular}




\section{TABLE VII}

Abnormal immunoglobulins, elevated total serum proteins, antinuclear factor (ANF), smooth muscle antibody (SMA), antimitochondrial antibody (AMA) in each group of patients.

\begin{tabular}{|c|c|c|c|c|c|c|}
\hline $\begin{array}{l}\text { Patient } \\
\text { group }\end{array}$ & $\begin{array}{l}\text { Number of } \\
\text { patients }\end{array}$ & $\begin{array}{l}\text { Abnormal } \\
\text { Immunoglo- } \\
\text { bulins }\end{array}$ & $\begin{array}{c}\text { Total serum } \\
\text { proteins } \\
80 \mathrm{~g} / 1\end{array}$ & ANF & SMA & AMA \\
\hline $\begin{array}{l}\text { Drug abusers } \\
\text { with CAH }\end{array}$ & 12 & $\begin{array}{c}3 \text { (2 returned } \\
\text { to normal) }\end{array}$ & - & - & 1 & - \\
\hline $\begin{array}{l}\text { Non abusers } \\
\text { With CAH }\end{array}$ & 10 & 5 & 3 & 3 & 2 & - \\
\hline $\begin{array}{l}\text { Drug abusers } \\
\text { With CPH }\end{array}$ & 12 & 3 & - & - & - & - \\
\hline $\begin{array}{l}\text { Non abusers } \\
\text { With CPH }\end{array}$ & 7 & - & - & 1 & 2 & - \\
\hline
\end{tabular}

\section{Histology (Tables IX-XII)}

Four of the drug abusing patients had chronic active hepatitis with cirrhosis on their initial biopsy; on follow up biopsy one showed histological deterioration with hepatocellular necrosis, marked swelling of the portal tracts and a heavy mononuclear cell infiltrate; whilst 2 were basically unchanged although one showed less cellular activity, and one had no repeat biopsy. Three patients with chronic active hepatitis on initial biopsy showed less cellular activity and no progression in the degree of fibrosis on repeat biopsy; one of these had a third biopsy and another a fourth biopsy

TABLE VIII

$\mathrm{HB}_{\mathrm{s}} \mathrm{A}_{\mathrm{g}}$ status in each group of patients.

\begin{tabular}{lccccc}
\hline $\begin{array}{l}\text { Patient } \\
\text { group }\end{array}$ & $\begin{array}{c}\text { Number of } \\
\text { patients }\end{array}$ & $\begin{array}{c}\mathrm{HB}_{\mathrm{s}} \mathrm{A}_{\mathrm{g}} \\
\text { positive }\end{array}$ & $\begin{array}{c}\mathrm{HB}_{\mathrm{s}} \mathrm{A}_{\mathrm{g}} \\
\text { positive } \\
\text { in past }\end{array}$ & $\begin{array}{c}\mathrm{HB}_{\mathrm{s}} \mathrm{A}_{\mathrm{g}} \text { and } \\
\text { antibody } \\
\text { negative }\end{array}$ & $\begin{array}{c}\mathrm{HB}_{\mathrm{s}} \mathrm{A}_{\mathrm{g}} \\
\text { negative }\end{array}$ \\
\hline $\begin{array}{l}\text { Drug abusers } \\
\text { with CAM }\end{array}$ & 12 & 5 & 4 & 3 & - \\
$\begin{array}{l}\text { Non abusers } \\
\text { with CAH }\end{array}$ & 10 & 4 & - & 6 & 6 \\
$\begin{array}{l}\text { Drug abusers } \\
\text { with CPH }\end{array}$ & 12 & 3 & 2 & - & 6 \\
$\begin{array}{l}\text { Non abusers } \\
\text { with CPH }\end{array}$ & 7 & 1 & - & 6 \\
\hline
\end{tabular}




\section{TABLE IX}

CAH. Histology in drug abusers.

(Time in months from initial biopsy in brackets).

\begin{tabular}{|c|c|c|c|}
\hline 1st Biopsy & 2nd Biopsy & 3rd Biopsy & 4th Biopsy \\
\hline Cirrhosis & Cirrhosis (11) & $\begin{array}{l}\text { Cirrhosis with } \\
\text { less activity (20) }\end{array}$ & \\
\hline Cirrhosis & Cirrhosis (8) & & \\
\hline Cirrhosis & Cirrhosis (6) & $\begin{array}{l}\text { Cirrhosis with } \\
\text { more activity (23) }\end{array}$ & \\
\hline Cirrhosis & - & & \\
\hline $\mathrm{CAH}$ & $\mathrm{CAH}$ with less & $\begin{array}{l}\text { CPH (20) } \\
\text { activity (12) }\end{array}$ & СРН (32) \\
\hline $\mathrm{CAH}$ & $\begin{array}{l}\text { Minor } \\
\text { Changes (32) }\end{array}$ & & \\
\hline $\mathrm{CAH}$ & $\begin{array}{l}\text { CAH with less } \\
\text { activity (10) }\end{array}$ & СРH (18) & \\
\hline CAH & CAH (8) & & \\
\hline $\mathrm{CAH}$ & CAH with more & & \\
\hline & $\begin{array}{l}\text { Activity and } \\
\text { Fibrosis }(6)\end{array}$ & & \\
\hline $\mathrm{CAH}$ & $\begin{array}{l}\text { CAH with less } \\
\text { activity more } \\
\text { fibrosis (6) }\end{array}$ & & \\
\hline $\mathrm{CAH}$ & $\begin{array}{l}\text { CAH with less } \\
\text { activity (30) }\end{array}$ & & \\
\hline $\mathrm{CAH}$ & - & & \\
\hline
\end{tabular}

showing chronic persistent hepatitis. One patient with chronic active hepatitis showed less cellular activity but more fibrosis on repeat biopsy. One patient had minor changes only on repeat biopsy.

Seven of 10 non drug abusing patients with chronic active hepatitis had cirrhosis on initial biopsy; one of these progressively improved showing minor changes only on a fifth biopsy. Two patients showed less cellular activity on repeat biopsy. Three patients without cirrhosis on initial biopsy progressed to it.

Ten of 12 drug abusers with chronic persistent hepatitis were essentially unchanged on repeat biopsy. One patient had chronic active hepatitis on a third biopsy and chronic active hepatitis with cirrhosis on a fourth biopsy. One patient had minor changes on a second biopsy and chronic persistent hepatitis on a third.

In the non drug abusing patients with chronic persistent hepatitis no patient progressed to chronic active hepatitis with or without cirrhosis, although one patient showed increased fibrosis on a-second biopsy. Four patients were unchanged on a second biopsy; one of these had minor changes on a third biopsy and normal histology on a fourth biopsy. One patient who had chronic persistent hepatitis on initial biopsy had minor changes on a second biopsy, 
TABLE X

$\mathrm{CAH}$. Histology in non drug abusing patients.

(Time in months from initial biopsy in brackets).

\begin{tabular}{|c|c|c|c|c|c|}
\hline 1st Biopsy & 2nd Biopsy & 3rd Biopsy & 4th Biopsy & 5th Biopsy & 6th Biopsy \\
\hline $\begin{array}{l}\text { CAH with } \\
\text { early } \\
\text { cirrhosis }\end{array}$ & $\begin{array}{l}\text { Established } \\
\text { cirrhosis more } \\
\text { activity (22) }\end{array}$ & Cirrhosis (32) & Cirrhosis (45) & & \\
\hline $\begin{array}{l}\text { CAH with } \\
\text { early } \\
\text { cirrhosis }\end{array}$ & $\begin{array}{l}\text { Increased } \\
\text { activity } \\
\text { increased } \\
\text { fibrosis (5) }\end{array}$ & $\begin{array}{l}\text { Cirrhosis with } \\
\text { less activity } \\
(20)\end{array}$ & Cirrhosis (32) & Cirrhosis (44) & \\
\hline $\begin{array}{l}\text { CAH with } \\
\text { cirrhosis }\end{array}$ & $\begin{array}{l}\text { Cirrhosis with } \\
\text { less cellular } \\
\text { activity (6) }\end{array}$ & $\begin{array}{l}\text { Fibrosis less } \\
\text { obvious (40) }\end{array}$ & $\begin{array}{l}\text { Minor changes } \\
(60)\end{array}$ & & \\
\hline $\begin{array}{l}\text { CAH with } \\
\text { cirrhosis }\end{array}$ & $\begin{array}{l}\text { Cirrhosis with } \\
\text { continuing } \\
\text { activity (10) }\end{array}$ & Cirrhosis (24) & & & \\
\hline $\mathrm{CAH}$ & $\begin{array}{l}\text { CAH with early } \\
\text { cirrhosis ( } 24)\end{array}$ & $\begin{array}{l}\text { Established } \\
\text { cirrhosis (33) }\end{array}$ & $\begin{array}{l}\text { Cirrhosis- } \\
\text { Progressive } \\
\text { severity (42) }\end{array}$ & Cirrhosis (54) & Cirrhosis (70) \\
\hline $\mathrm{CAH}$ & $\begin{array}{l}\text { CAH with early } \\
\text { cirrhosis (6) }\end{array}$ & $\begin{array}{l}\text { Established } \\
\text { cirrhosis (15) }\end{array}$ & Cirrhosis (29) & & \\
\hline CAH & $\begin{array}{l}\text { CAH with } \\
\text { cirrhosis (12) }\end{array}$ & Cirrhosis (60) & & & \\
\hline $\begin{array}{l}\text { CAH with } \\
\text { cirrhosis }\end{array}$ & $\begin{array}{l}\text { CAH with } \\
\text { cirrhosis (12) }\end{array}$ & $\begin{array}{l}\text { Progressive } \\
\text { cirrhosis (24) }\end{array}$ & & & \\
\hline $\begin{array}{l}\text { CAH with } \\
\text { cirrhosis }\end{array}$ & $\begin{array}{l}\text { Cirrhosis with } \\
\text { less activity } \\
\text { (12) }\end{array}$ & & & & \\
\hline $\begin{array}{l}\text { CAH with } \\
\text { cirrhosis }\end{array}$ & $\begin{array}{l}\text { Cirrhosis with } \\
\text { less cellular } \\
\text { activity (14) }\end{array}$ & & & & \\
\hline
\end{tabular}

\section{TABLE XI}

CPH. Histology in drug abusers.

(Time in months from initial biopsy in brackets).

\begin{tabular}{lll}
\hline 1st Biopsy & 2nd Biopsy & 3rd Biopsy \\
\hline CPH & CPH (22) & \\
CPH & CPH (6) & \\
CPH & CPH (7) & \\
CPH & CPH (6) & \\
CPH & CPH (15) & \\
CPH & CPH (22) & \\
CPH & CPH (6) & \\
CPH & CPH (9) & CPH (17) \\
CPH & CPH (10) & CAH with \\
CPH & CPH (48) & cirrosis (13) \\
CPH & Minor changes (3) & \\
CPH & CAH (6) & \\
\end{tabular}

chronic persistent hepatitis on a third and minor changes on a fourth biopsy.

In addition to the other changes described fatty infiltration was found in one drug abusing patient with chronic active hepatitis, one drug abuser with chronic persistent hepatitis, one non drug abusing patient with chronic active hepatitis and 2 non drug abusing patients with chronic persistent hepatitis. 


\section{Discussion}

Several interesting findings emerged from this study. In both histological groups the mean age of the drug abusers was younger and the mean duration of follow up shorter than in the non drug abusers. Of those patients with chronic active hepatitis there were 5 men and 5 women in the non drug abusing group compared with 11 men and one woman in the drug abusers. There was more clinical evidence of liver disease in the non drug abusing patients with chronic active hepatitis in whom 6 of 10 had stigmata of liver disease compared

TABLE XII

$\mathrm{CPH}$. Histology in non drug abusers.

(Time in months from initial biopsy in brackets).

\begin{tabular}{cccc}
\hline 1st Biopsy & 2nd Biopsy & 3rd Biopsy & 4th Biopsy \\
\hline $\mathrm{CPH}$ & CPH with more & & \\
& fibrosis (36) & & \\
$\mathrm{CPH}$ & $\mathrm{CPH} \mathrm{(12)}$ & & \\
$\mathrm{CPH}$ & $\mathrm{CPH} \mathrm{(27)}$ & & \\
$\mathrm{CPH}$ & $\mathrm{CPH} \mathrm{(33)}$ & Minor changes (23) & Minor changes (36) \\
$\mathrm{CPH}$ & $\mathrm{CPH}(3)$ & CPH (24) & Normal (42) \\
$\mathrm{CPH}$ with acute & Minor changes (7) & & \\
hepatitis & Minor changes (5) & Minor changes (20) & \\
$\mathrm{CPH}$ & & & \\
\hline
\end{tabular}

with only 3 of 12 drug abusers. More patients in the non drug abusing group had abnormal serum proteins and immunoglobulins. Nine of 12 drug abusers had past or present evidence of hepatitis B virus; infection compared with 4 of 10 non drug abusers. No drug abusing patient without cirrhosis on initial biopsy developed it although one patient showed more fibrosis and more cellular activity on repeat biopsy. Two patients showed chronic persistent hepatitis on follow up biopsy and one patient showed minor changes only.

The non drug abusing group of patients with chronic active hepatitis had histologically more advanced disease than the drug abusers. Seven of 10 patients had cirrhosis on initial biopsy and the remaining 3 developed it. One patient showed apparent histological recovery. The higher frequency of abnormality of immunoglobulins, serum proteins, antinuclear factor and smooth muscle antibody together with the greater number of females in this group would suggest that those patients who were $\mathrm{HB}_{\mathrm{s}} \mathrm{Ag}$ negative had chronic active hepatitis of the lupoid variety. This tends to have a poor prognosis with cirrhosis developing rapidly (Sherlock, 1974) which would correlate with the findings in this study.

Sherlock (1974) believes that $\mathrm{HB}_{\mathrm{s}} \mathrm{A}_{\mathrm{g}}$ associated chromic active hepatitis had a better prognosis than the lupoid type. Although this is not a universally held belief (De Groote, Fevery and Lepourtre, 1978) our study would appear to support it. Spontaneous remissions of chronic active hepatitis have been reported (Soloway et at, 1972; Summershill, 1974); the presence of cirrhosis does not preclude remission (Soloway et al, 1972). This may account for the 2 histological remissions which occurred, one in the drug abusing and the other in the non abusing group.

In this study the histological abnormality of chronic persistent hepatitis tended to persist (10 of 12) or progress (one of 12) in the drug abusing patients while in the non drug abusing patients spontaneous remission tended to occur more frequently with minor changes only remaining in the liver. The benign nature of chronic persistent hepatitis previously documented (Becker et al, 1970) is thus confirmed. Recently progression of chronic persistent hepatitis to chronic active hepatitis has been described (Chadwick et al, 1970). It is felt by some people that between the histological diagnosis of chronic active and chronic persistent hepatitis there is a continuum of histologic abnormality (Scheurer, 1977); and progression of chronic persistent hepatitis to cirrhosis has been documented (Van Waes et al, 1974; Dietrichson, 1975). Apparent histological remission of chronic persistent hepatitis as occurred in our study has also been described; in Dietrichson's study (1975) 16 patients with chronic 
persistent hepatitis had one or more repeat biopsies; 3 patients had non specific portal tract changes and one patient had no histological abnormality on repeat biopsy. Sherlock and her associates (1979) describe apparent remission in one patient of 16 with chronic persistent hepatitis.

We are aware of the limitations of conclusions based in individual biopsies but repeated biopsies on individuals and 2 or more biopsies in a number of patients allow firmer deductions to be made. Chronic active hepatitis tends to be less severe histologically and progress to cirrhosis less frequently in drug abusers than in non abusers; while the histological changes of chronic persistent hepatitis tend to persist or progress to chronic active hepatitis In drug abusers and regress in non drug abusers. Such persistence or progression in drug abusers may be related to continued drug abuse as the majority of our drug abusing patients continued to abuse drugs.

\section{References}

Becker, M. D., Baptista, A., Scheurer, P. J., Sherlock, S. 1970. Lancet i, 53-57.

Chadwick, R. G., Galizzi, J., Heathcote, T., Lyssiotis, T., Cohen, B. J., Bcheurer, P. J. and Sherlock, S. 1970. Gut 20, 372-377.

De Groote, J., Pevery, J. and Lepourtre, L. 1978. Gut 19, 510-153.

Dietrichson, O., Scard, J. 1975. Gastroenterology 10, 249-255.

McCance, R. A., Widdowson, E. M. 1967. Spec. Rep. Scr. Med. Res. Count. Lon. No. 297.

Review by an International Group. 1977. Lancet ii, 914-919.

Scheurer, P. J. 1977. Histopathology i, 5-19.

Sherlock, Sheila. 1974. Gut 15, 581-597.

Soloway, R. D., Summerskill, W. H. J., Baggenstoss, A. H., Geall, M. G., Sitnick, G., Elvehack, L. R. and Schoenfield, L. J. 1972. Gastroenterology 63, 5, 820-833.

Summerskill, W. H. J. 1974. Gastroenterology 66, 450-464.

Van Waes, L., Segers, J., Van Edmond, J., Van Nimmen, L., Barhier, F., Wieme, R. and Demeulencre, L. 1974. Brit. Med. J. iii, 444-446. 